\title{
Determination of Burnout and Job Satisfaction Levels in Nurses Working in the Surgical Clinics
}

\section{Cerrahi Kliniğinde Çalışan Hemşirelerde Tükenmişlik ve İş Tatmini Düzeylerinin Belirlenmesi}

\author{
(D) Nermin Karahaliloğlu1, (D Kürşat Özdilli², (D) Elif Yorulmaz, (D Hatice Yorulmaz ${ }^{4}$ \\ 1T.C. İstanbul Şişli Vocational School, First and Emergency Aid Program, İstanbul, Turkey \\ 2İstanbul Medipol University Hospital, Clinic of Oncology, İstanbul, Turkey \\ ${ }^{3}$ University of Health Sciences, İstanbul Bağcılar Training and Research Hospital, Clinic of Gastroenterology, İstanbul, Turkey \\ ${ }^{4}$ Haliç University, School of Nursing, Division of Nursing, İstanbul, Turkey
}

\section{Abstract}

Objective: The aim of this study was to assess the effect of sociodemographic and professional characteristics of nurses working in the surgical services on their burnout and job satisfaction levels.

Method: The study was conducted with 95 nurses, who were voluntary to participate in the study, among 104 nurses working in the surgical services (except for outpatient clinics and emergency surgery units). Introductory information form, Maslach Burnout Inventory, and Minnesota Satisfaction Questionnaire were used in order to collect the data. The statistical analysis was performed using frequency and percentage distribution, t-test, one-way analysis of variance, Tukey test, Kruskal-Wallis test, and Mann-Whitney U test.

Results: It was found that $78.9 \%$ of the nurses were female, $28.4 \%$ were in the age group of $30-34$ years, $38.9 \%$ had a bachelor's degree, $56.8 \%$ were single, $46.3 \%$ were working in the institution for $0-3$ years, $57.9 \%$ had no children, $64.2 \%$ had an income equal to expenses, and $60 \%$ used public transportation. It was observed that the emotional exhaustion and depersonalization subscale scores of the nurses were higher in the age group of 25-29 years than the age group of 20-24 years $(p<0.05)$ and 40 years and over (emotional exhaustion $p<0.01$; depersonalization, $p<0.05)$. It was determined that the depersonalization subscale scores of those without children were higher than those having two and more children $(p<0.05)$. Personal accomplishment subscale scores of the nurses working for 9-11 years were lower than the other groups. It was observed that those having a working year of 1-3 years had higher scores on extrinsic satisfaction than those having a working year of 4-8 years $(p<0.05)$. All score of nurses who chose the profession due to finding a job quickly was significantly lower than the other groups $(p<0.05)$. It was determined that intrinsic, extrinsic and general satisfaction of those who

\section{Öz}

\begin{abstract}
Amaç: $\mathrm{Bu}$ çalışma, cerrahi servislerinde çalışan hemşirelerde sosyodemografik ve mesleki özelliklerin, tükenmişlik ve iş doyumu düzeylerine etkisinin değerlendirilmesi amacıyla yapıldı.
\end{abstract}

Yöntem: Araştırma cerrahi servislerinde çalışan (poliklinikler ve acil cerrahi birimler dışında) 104 hemşireden çalışmaya katılmayı gönüllü olarak kabul eden 95'i ile gerçekleştirildi. Verileri toplamak amacıyla hemşirelere tanıtıcı bilgi formu, Maslach Tükenmişlik Ölçeği ve Minnesota Doyum Ölçeği uygulandı. İstatistiksel analizde; frekans ve yüzde dağılımı, t-test, tek yönlü varyans analizi, Tukey testi, Kruskal-Wallis test, MannWhitney $\mathrm{U}$ testleri kullanıldı.

Bulgular: Hemşirelerin \%78,9'unun kadın, \%28,4'ünün 30-34 yaş grubunda, \%38,9'u lisans mezunu, \%56,8'i bekar olduğu, \%46,3'ünün 0-3 yıldır kurumda çalıştığı, \%57,9'unun çocuk sahibi olmadığı, \%64,2'sinin gelirinin gidere eşit olduğu, \%60'ının toplu taşımayla ulaşım sağladığı saptandı. Yirmi beş-yirmi dokuz yaş grubu hemşirelerin duygusal tükenme ve duyarsızlaşma alt boyut puanlarının 20-24 yaş grubundan $(p<0,05)$, 40 yaş ve üzeri hemşirelerden (duygusal tükenme $p<0,01$; duyarsılaşma, $p<0,05)$ daha yüksek olduğu görüldü. Çocuk sahibi olmayanların duyarsızlaşma alt boyutu puanlarının iki ve daha fazla çocuk sahibi olanlardan daha yüksek olduğu saptandı $(p<0,05)$. Dokuz-onbir yıldır çalışan hemşirelerin kişisel başarı alt boyutu puanı 4-8 yıl $(p<0,05)$ ve 16 yıl ve üzeri çalışanlardan $(p<0,001)$ yüksek olduğu saptandı. Çalışma yılı 0-3 yıl olanların dışsal doyumdan 4-8 yıl olanlara göre daha yüksek puan aldıkları görüldü $(p<0,05)$. Kısa yoldan iş sahibi olma nedeni ile mesleği seçenlerin içsel, dışsal doyum alt boyut puanları ve toplam puanının diğer tüm gruplara göre düşük olduğu saptandı $(p<0,05)$. Geliri giderinden yüksek olanların içsel, dışsal ve genel, servis aracıyla gelenlerin dışsal ve genel, yıllık izin süresi iki hafta olanların üç hafta olanlara göre iş doyumu,

Address for Correspondence: Elif Yorulmaz, T.C. İstanbul Şişli Vocational School, First and Emergency Aid Program, İstanbul, Turkey E-mail: elifdahiliye@gmail.com ORCID ID: orcid.org/0000-0002-2476-1328 Received: 24.11.2018 Accepted: 06.05.2019

Cite this article as: Karahaliloğlu N, Özdilli K, Yorulmaz E, Yorulmaz H. Determination of Burnout and Job Satisfaction Levels in Nurses Working in the Surgical Clinics. Bagcilar Med Bull 2019;4(2):31-41

${ }^{\circ}$ Copyright 2019 by the Health Sciences University, Bagcilar Training and Research Hospital Bagcilar Medical Bulletin published by Galenos Publishing House. 


\section{Abstract}

had higher income than expenses, extrinsic and general satisfaction of those who came with shuttle, and job satisfaction, general satisfaction score and subscale scores of those having two weeks of annual leave were higher than those having annual leave of three weeks $(p<0.05)$. Also, the burnout and job satisfactions of the nurses were moderate and there was a negative correlation between the burnout and job satisfaction $(p<0.05)$.

Conclusion: It was observed that nurses which age group of 25-29 years, without children, who worked for 9-11 years in the institution burnout levels were high. At the same time, nurses which with high economic status, transporting with shuttle, who used a 2-week annual leave, who did not chose the profession due to finding a job quickly had higher job satisfaction. Organizing the regulations that will increase the work motivation of the nurses will reduce the emotional exhaustion and depersonalization.

Keywords: Surgical, nurse, job satisfaction, burnout

\section{Öz}

genel doyum puanı ve alt boyutları puanı daha yüksek saptandı $(p<0.05)$, Hemşirelerin tükenmişlik ve iş doyumlarının orta düzeyde olduğu, tükenmişlik ile iş doyumu arasında negatif yönde ilişki olduğu saptandı $(p<0.05)$.

Sonuç: Hemşirelerden 25-29 yaş grubundakilerin, çocuk sahibi olmayanların, kurumda bulunma süresi 9-11 yıl olanların tükenmişliklerinin yüksek olduğu görüldü. Aynı zamanda yüksek ekonomik duruma sahip olanların, kısa yoldan iş sahibi olma nedeni ile mesleği seçmeyenlerin, yıllık izin süresi iki hafta olanların, servis aracı kullananların iş doyumlarının yüksek olduğu görüldü. Hemşirelerin çalışma motivasyonunu artıracak düzenlenmelerin yapılması duygusal tükenmişlik ve duyarsızlaşmayı azaltacaktır.

Anahtar kelimeler: Cerrahi, hemşire, iş doyumu, tükenmişlik

\section{Introduction}

Burnout can be defined as a condition accompanied by symptoms such as physical exhaustion and the development of negative attitudes towards employees and life resulting from long-term working in environments with intense emotional demands (1). Job satisfaction signifies the harmony between the properties of the work and the properties that individuals find in themselves. The job satisfaction is determined by the differences that arise when the nurses compare their own standards with how much of those standards are met (2). An individual hospitalized due to surgical causes may exhibit many negative feelings, thoughts and behaviors related to his/her disease or hospital setting. As a result, job dissatisfaction and burnout symptoms such as getting away from the job, leaving the job and frequently changing the job can be seen (3). It is very important for nurses working in the surgical clinics to have knowledge and intention about patient education, to determine the needs and goals specific for the clinic and the patient, and to maintain communication (4). Piko (5) determined that problems associated with burnout reduce the efficiency of nurses, cause job dissatisfaction, and obstruct professionalism. Operating room medical staff are exposed to many potential hazards, including occupational traumatization, work stress, toxic and infectious agents, radiation, noise, anesthetic gases, working late into the night with a few people, working for extended periods in nonphysiological positions, and disturbances in the workplace that threaten the security of staff (6). This demanding nature of jobs and stress is found to be a cause of job burnout, but the construct of job burnout and its consequences in the health sector are not comprehensively reviewed (7). This study was conducted to determine the effect of socio-demographic characteristics and professional features of surgical nurses on their burnout and job satisfaction levels.

\section{Material and Methods}

A cross-sectional, descriptive correlational study was conducted with 95 surgical nurses who were voluntary to participate in the study, among 104 nurses employed in different surgical wards and clinics in a state hospital and five educational research hospitals (except for the outpatient clinics and emergency surgery units) in İstanbul after the approval of Haliç University Ethics Committee was received (decision number: 44-2012). Introductory information form, Maslach Burnout Inventory, and Minnesota Satisfaction Questionnaire were applied to the nurses in order to collect the data.

\section{Introductory Information Form}

The introductory information form includes the questions related to the socio-demographic characteristics of the nurses such as gender, age, marital status, status of having a child, economic status, and educational status. Regarding the professional characteristics, there are questions about total working duration in the institution, reason for choosing the profession, way of transportation, and the time of annual leave. 


\section{Maslach Burnout Inventory}

It was translated into Turkish by Ergin (8) and the inventory was constructed with 22 items scored on a Likert scale from 0 (refers ton ever) to 4 (refers to always) according to the frequency with which stressors are perceived. The 22 items are composed by the subscales emotional exhaustion $(1,2$, $3,6,8,13,14,16,20$ items), depersonalization $(5,10,11,15$, 22 items) and personal accomplishment $(4,7,9,12,17,18$, 19, 21 items).

Scores from each of these subscales may be graded as high, moderate, or low according to validated cut-offs. Emotional exhaustion scores were graded as follows: low, 0-11 points; moderate, $12-17$ points and high, $18-36$ points. Depersonalization scores were graded as follows: low, $<4$ points; moderate, $4-6,6$ points and high, $\geq 6,7$ points; and personal accomplishment scores as: low $\geq 27$ points, $22-26$ points, moderate, $<22$ points.

\section{Minnesota Satisfaction Questionnaire}

It was developed in 1967 by Weiss, Dawis, England \& Lofquist. It was translated into Turkish by Baycan (9) and its validity and reliability studies were conducted. The Minnesota Satisfaction Questionnaire's indicates how satisfied or dissatisfied respondents are with their jobs by asking respondents to rate themselves on 20 questions by using a five-point scale (1: very dissatisfied to 5: very satisfied). The questionnaire gives intrinsic satisfaction subscale, extrinsic satisfaction subscale, and general satisfaction scores. The overall satisfaction score is obtained by dividing the total score of the all items into 20 , the intrinsic satisfaction by dividing the score of items (1.2.3.4.7.8.9.10.11.15.16.20) into 12, and the extrinsic satisfaction by dividing the score of items (5.6.12.13.14.17.18.19) into 8. Score increase indicates increased job satisfaction (9).

\section{Statistical Analysis}

The statistical analysis of the data was performed in the computer environment via SPSS 15.0 statistical analysis package program along with t-test, one-way analysis of variance, Tukey test, Kruskal-Wallis test, and MannWhitney U test.

\section{Results}

It was found that $78.9 \%$ of the nurses were female, $28.4 \%$ were in the age group of $30-34$ years, $38.9 \%$ had a bachelor's degree, $56.8 \%$ were single, $46.3 \%$ were working in the institution for $1-3$ years, $57.9 \%$ had no children, $64.2 \%$ had an income equal to their expenses, and $60 \%$ were using public transportation. Table 1 shows the frequency Table 1. Socio-demographic and professional variables of the nurses working in the surgical clinics $(n=95)$

\begin{tabular}{|c|c|c|c|c|c|c|c|}
\hline Variable & Variable categories & $\mathbf{n}$ & $\%$ & Variable & Variable categories & $\mathbf{n}$ & $\%$ \\
\hline \multirow{2}{*}{ Gender } & Female & 75 & 78.9 & \multirow{2}{*}{ Marital status } & Married & 441 & 43.2 \\
\hline & Male & 20 & 21.1 & & Single & 554 & 56.8 \\
\hline \multirow[b]{2}{*}{ Age group } & $25-29$ years & 26 & 27.4 & \multirow[t]{2}{*}{ Number of children } & 1 & 20 & 21.1 \\
\hline & $30-34$ years & 27 & 28.4 & & 2 and more & 20 & 21.1 \\
\hline \multirow{4}{*}{ Educational status } & Vocational high school & 25 & 26.4 & Economic status & Income > expense & 223 & 24.2 \\
\hline & Associate's degree & 22 & 23.2 & \multirow{3}{*}{ Transportation type } & On foot & 12 & 12.6 \\
\hline & Bachelor's degree & 37 & 38.9 & & With shuttle & 118 & 18.9 \\
\hline & Graduate's degree & 11 & 11.6 & & Public transportation & 557 & 60.0 \\
\hline \multirow{2}{*}{$\begin{array}{l}\text { Duration of working in the } \\
\text { institution }\end{array}$} & $12-15$ years & 7 & 7.4 & \multirow{2}{*}{$\begin{array}{l}\text { Time of annual } \\
\text { leave }\end{array}$} & 4 weeks & 330 & 31.6 \\
\hline & 16 years and more & 13 & 13.7 & & No night shift & 5 & 5.3 \\
\hline \multirow{5}{*}{$\begin{array}{l}\text { Reason for choosing the } \\
\text { Profession }\end{array}$} & Having a health-related job & 30 & 31.6 & \multirow{5}{*}{$\begin{array}{l}\text { Reason for working } \\
\text { in the institution }\end{array}$} & Close to home & 13 & 13.7 \\
\hline & Having a job quickly & 16 & 16.8 & & Non-heavy working conditions & 8 & 8.4 \\
\hline & Ease of employment & 21 & 22.1 & & Economic reasons & 13 & 13.7 \\
\hline & Family's suggestion & 23 & 24.2 & & Designation & 56 & 58.9 \\
\hline & Recommendation of others & 5 & 5.3 & & & & \\
\hline
\end{tabular}


and percentage distribution of socio-demographic and professional variables of the nurses.

\section{Maslach Burnout Inventory Results}

It was seen that the nurses took a mean score of $20.43 \pm 5.14$ from the personal accomplishment subscale; $18.27 \pm 7.33$ from the emotional exhaustion subscale; and $7.07 \pm 4.43$ from the depersonalization subscale of Maslach Burnout Inventory (Table 2). No significant difference was determined between the subscale scores of the nurses in terms of the variables of gender, marital status, educational status, economic status, choosing the profession, transportation, and annual leave period $(p>0.05)$. The emotional exhaustion and depersonalization subscale scores of the nurses were higher in the age group of 25-29 years than the age group of 20 -24 years $(\mathrm{p}<0.05)$ and 40 years and over (emotional exhaustion $\mathrm{p}<0.01$; depersonalization, $\mathrm{p}<0.05$ ).

It was found that depersonalization subscale scores of those with no children were higher than those with two or more children $(\mathrm{p}<0.05)$. Also, the personal accomplishment subscale scores of the nurses who worked for 9-11 years were lower than other all groups and the nurses who worked for 9-11 years have highest burnout $(\mathrm{p}<0.05)$ (Table 3$)$.

\section{Satisfaction Questionnaire Results}

It was found that the scores of the nurses were $3.27 \pm 0.66$ points for the intrinsic satisfaction subscale of the Minnesota Satisfaction Questionnaire, $2.85 \pm 0.75$ points for its extrinsic satisfaction subscale; and $3.10 \pm 0.65$ points for its general satisfaction subscale (Table 4).

The difference in the scale scores of the nurses in terms of the variables of age, gender, education, marital status, having children, reason for working in the institution and duration of working in the institution was not significant ( $p>0.05)$. Total score, intrinsic satisfaction subscale score and extrinsic satisfaction subscale score of those who chose the profession due to finding a job quickly was significantly lower than the other groups $(p<0.05)$. Total

\section{Table 2. Burnout Inventory scores of the nurses $(n=95)$}

\begin{tabular}{llll} 
Scale & Subscale & Mean \pm SD & $\begin{array}{l}\text { Degree of } \\
\text { burnout }\end{array}$ \\
\hline \multirow{3}{*}{$\begin{array}{l}\text { Burnout } \\
\text { inventory }\end{array}$} & $\begin{array}{l}\text { Personal } \\
\text { accomplishment }\end{array}$ & $20.43 \pm 5.14$ & High \\
& Emotional exhaustion & $18.27 \pm 7.33$ & High \\
& Depersonalization & $7.07 \pm 4.43$ & High \\
\hline
\end{tabular}

SD: Standard deviation score and subscale scores of the nurses with high economic status were significantly higher than those with moderate and low economic status $(\mathrm{p}<0.05)$. Intrinsic and extrinsic satisfaction subscale scores of those with high economic status were higher than the nurses with low economic status $(p<0.001)$. Total scores and extrinsic satisfaction subscale scores of the nurses transporting with shuttle were higher than those who used public transportation and their own cars $(\mathrm{p}<0.05)$. Total score and subscale scores of the nurses who used a 2-week annual leave were higher than the nurses who used a 3-week annual leave $(p<0.05)$ (Table 5).

According to the correlation analysis conducted between total score of the Minnesota Satisfaction Questionnaire and subscale scores of the Maslach Burnout Inventory; it was found that there was a negative weak insignificant correlation between the personal accomplishment subscale scores of the burnout inventory and the job satisfaction scores $(\mathrm{r}=0.07 ; \mathrm{p}>0.05)$; a negative significant and strong correlation between the emotional exhaustion subscale scores of the burnout inventory and the job satisfaction scores $(r=0.50 ; p<0.001)$; and a negative significant weak correlation between the depersonalization subscale score of the burnout inventory and the job satisfaction scores $(\mathrm{r}=0.19 ; \mathrm{p}<0.05)$.

\section{Discussion}

It was found in the present study that the level of personal accomplishment were low, the level of emotional exhaustion and depersonalization were high. The points from all three subscales indicate that nurses are very exhausted. Intensive care and internal service nurses have to deal with many different subjects and areas at the same time. The responsibility that occurs in the surgical departments, the limitation of authority has a higher motivation than the nurses working they are provided. Most of the study showed burnout score levels are higher in surgical departments $(10,11,12)$.

Nurses working in operation room suffer from higher levels of emotional fatigue than nurses working in surgical ward. In general, the study shows that nurses working in surgical ward suffer from higher levels of emotional fatigue and depersonalization than nurses working in other departments (13).

In this study, it was seen that while job satisfaction of the nurses was high (3.10 \pm 0.65$)$, their intrinsic satisfaction $(2.94 \pm 0.62)$ and extrinsic satisfaction $(2.85 \pm 0.75)$ were low. 
Table 3. Burnout Inventory Scores of the nurses in term of socio-demographic and professional variables ( $\mathrm{n=95}$ )

\section{Subscales}

\begin{tabular}{l} 
Variable \\
\hline Gender \\
Age
\end{tabular}

Marital status

Number of children

Educational status

Duration of Working in the institution
Married

Single

Test values

\section{Variable categories}

Female
Male

Test values

20-24 years $^{1}$

25-29 years $^{2}$

30-34 years 3

35-39 years ${ }^{4}$

40 years and over 5

Test values

None ${ }^{0}$

1 child $^{1}$

2 children and more ${ }^{2}$

Test values

Vocational high school ${ }^{1}$

Associate's degree ${ }^{2}$

Bachelor's degree ${ }^{3}$

Graduate's degree 4

Test values

1-3 years

4-8 years $^{2}$

9-11 years $^{3}$

$12-15$ years $^{4}$

16 years and more 5

Test values $\mathrm{t}=0.009 \mathrm{p}=0.92$

Personal accomplishment
(0-32 points)
Mean \pm SD

$20.46 \pm 4.79$

$20.35 \pm 6.45$

$t=0.12 p=0.89$

$19.10 \pm 5.59$

$22.03 \pm 4.66$

$19.03 \pm 5.59$

$20.08 \pm 3.20$

$22.72 \pm 4.92$

$F=2.09 p=0.08$

$1-2 p=0.30,1-3 p=1.00$

$1-4 p=0.98,1-5 p=0.32$

$2-3 p=0.20,2-4 p=0.79$

$2-5 p=0.99,3-4 p=0.97$

$3-5 p=0.2,4-5 p=0.71$

$20.48 \pm 4.97$

$20.38 \pm 5.32$

$20.96 \pm 4.95$

$19.75 \pm 5.96$

$19.65 \pm 4.88$

$\mathrm{F}=0.69 \mathrm{p}=0.50$

$0-1 p=0.64,0-2 p=0.59$

$1-2 p=0.98$

$21.75 \pm 5.16$

$18.86 \pm 5.80$

$20.59 \pm 4.03$

$19.36 \pm 6.36$

$F=1.7 p=0.14$

$1-2 p=0.15,1-3 p=0.69$

$1-4 p=0.47,2-3 p=0.58$

$2-4 p=0.99,3-4 p=0.89$

$20.63 \pm 4.76$

$21.27 \pm 5.48$

$15.33 \pm 5.97$

$19 \pm 2.08$

$22.61 \pm 4.5$

$\mathrm{KW}=3.40 \mathrm{p}=0.01$

$1-2 p=0.98,1-3 p=0.03 *$

$1-4 p=0.93,1-5 p=0.70$

$2-3 p=0.02 *, 2-4 p=0.82$

$2-5 p=0.93,3-4 p=0.04 *$

$3-5 p=0.00 * *, 4-5 p=0.51$

Emotional exhaustion
(0-36 points)
Mean \pm SD

$20.46 \pm 6.54$

$20.30 \pm 6.72$

$\mathrm{t}=0.78 \mathrm{p}=0.43$

$16.42 \pm 5.02$

$20.88 \pm 8.15$

$16.74 \pm 6.15$

$19.75 \pm 5.01$

$14.90 \pm 4.82$

$\mathrm{F}=2.79 \mathrm{p}=0.03$ *

$1-2 p=0.05^{*}, 1-3 p=1.00$

$1-4 p=0.61,1-5 p=0.97$

$2-3 p=0.13,2-4 p=0.98$

$2-5 p=0.01 *, 3-4 p=0.64$

$3-5 p=0.9,4-5 p=0.36$

$18.60 \pm 5.32$

$17.50 \pm 6.29$

$t=0.66 p=0.41$

$18.65 \pm 6.53$

$18.20 \pm 7.66$

$15.90 \pm 5.24$

$F=1.31 p=0.27$

$0-1 p=0.96,0-2 p=0.24$

$1-2 p=0.51$

$17.72 \pm 6.85$

$16.09 \pm 5.94$

$18.21 \pm 5.87$

$19.62 \pm 9.10$

$\mathrm{F}=0.93 \mathrm{p}=0.47$

$1-2 p=0.31,1-3 p=0.89$

$1-4 p=0.89,2-3 p=0.62$

$2-4 p=0.90,3-4 p=0.89$

$17.79 \pm 6.69$

$21.68 \pm 9.33$

$13.66 \pm 5.52$

$18.57 \pm 4.72$

$17.15 \pm 6.14$

$\mathrm{KW}=1.86 \mathrm{p}=0.12$

$1-2 p=0.53,1-3 p=0.41$

$1-4 p=0.99,1-5 p=0.99$

$2-3 p=0.07,2-4 p=0.96$

$2-5 p=0.60,3-4 p=0.56$

$3-5 p=0.73,4-5 p=0.99$

\section{Depersonalization (0-20 points) Mean \pm SD}

$6.65 \pm 4.31$

$8.65 \pm 4.65$

$\mathrm{t}=1.80 \mathrm{p}=0.07$

$6.00 \pm 3.17$

$9.34 \pm 5.26$

$6.88 \pm 4.10$

$6.50 \pm 3.28$

$4.63 \pm 4.41$

$\mathrm{F}=3.13 \mathrm{p}=0.01^{*}$

$1-2 p=0.05 *, 1-3 p=0.95$

$1-4 p=0.99,1-5 p=0.91$

$2-3 p=0.22,2-4 p=0.31$

$2-5 p=0.02 * 3-4 p=0.99$

$3-5 p=0.5,4-5 p=0.83$

$7.80 \pm 4.37$

$6.51 \pm 4.44$

$t=1.97 p=0.16$

$7.96 \pm 4.20$

$6.55 \pm 5.41$

$5.15 \pm 3.37$

$\mathrm{F}=3.27 \mathrm{p}=0.04^{*}$

$0-1 \mathrm{p}=0.42,0-2 \mathrm{p}=0.03^{*}$

$1-2 \mathrm{p}=0.56$

$8.20 \pm 5.11$

$6.45 \pm 4.02$

$6.13 \pm 3.65$

$9.36 \pm 5.33$

$F=1.98 p=0.11$

$1-2 \mathrm{p}=0.62,1-3 \mathrm{p}=0.35$

$1-4 p=0.82,2-3 p=0.99$

$2-4 p=0.27,3-4 p=0.14$

$7.70 \pm 4.61$

$7.72 \pm 4.92$

$6.44 \pm 3$

$4.42 \pm 3.3$

$5.69 \pm 3.9$

$\mathrm{KW}=1.34 \mathrm{p}=0.26$

$1-2 p=1.00,1-3 p=0.93$

$1-4 p=0.36,1-5 p=0.60$

$2-3 p=0.94,2-4 p=0.42$

$2-5 p=0.68,3-4 p=0.89$

$3-5 p=0.99,4-5 p=0.97$ 


\section{Table 3. Continued}

\begin{tabular}{|c|c|c|c|c|}
\hline \multirow[b]{2}{*}{ Variable } & \multirow[b]{2}{*}{ Variable categories } & \multicolumn{3}{|c|}{ Subscales } \\
\hline & & $\begin{array}{l}\text { Personal accomplishment } \\
\text { (0-32 points) } \\
\text { Mean } \pm \text { SD }\end{array}$ & $\begin{array}{l}\text { Emotional exhaustion } \\
\text { (0-36 points) } \\
\text { Mean } \pm \mathrm{SD}\end{array}$ & $\begin{array}{l}\text { Depersonalization } \\
(0-20 \text { points }) \\
\text { Mean } \pm \text { SD }\end{array}$ \\
\hline \multirow{11}{*}{$\begin{array}{l}\text { Reason for choosing the } \\
\text { profession }\end{array}$} & Having a health-related job¹ & $20.60 \pm 6.04$ & $15.93 \pm 6.10$ & $6 \pm 3.93$ \\
\hline & Finding a job quickly² & $18.75 \pm 3.49$ & $17.37 \pm 6.20$ & $7.5 \pm 5.17$ \\
\hline & Ease of employment ${ }^{3}$ & $20.42 \pm 4.88$ & $19.19 \pm 5.50$ & $8 \pm 3.98$ \\
\hline & Family's suggestion & $20.82 \pm 4.81$ & $20.30 \pm 6.96$ & $7.69 \pm 4.79$ \\
\hline & Recommendation of others 5 & $23.00 \pm 6.70$ & $16.40 \pm 10.35$ & $5.40 \pm 5.02$ \\
\hline & Test values & $\mathrm{KW}=0.77 \mathrm{p}=0.54$ & $K W=1.79 p=0.13$ & $K W=0.99 p=0.49$ \\
\hline & & $1-2 p=0.77,1-3 p=1.00$ & $1-2 p=0.95,1-3 p=0.39$ & $1-2 p=0.81,1-3 p=0.51$ \\
\hline & & $1-4 p=1.00,1-5 p=0.87$ & $1-4 p=0.11,1-5 p=1.00$ & $1-4 p=0.64,1-5 p=0.99$ \\
\hline & & $2-3 p=0.86,2-4 p=0.73$ & $2-3 p=0.91,2-4 p=0.63$ & $2-3 p=0.99,2-4 p=1.00$ \\
\hline & & $2-5 p=0.49,3-4 p=0.99$ & $2-5 p=0.99,3-4 p=0.97$ & $2-5 p=0.88,3-4 p=0.99$ \\
\hline & & $3-5 p=0.85,4-5 p=0.91$ & $3-5 p=0.90,4-5 p=0.73$ & $3-5 p=0.76,4-5 p=0.83$ \\
\hline \multirow{11}{*}{$\begin{array}{l}\text { Reason for working in } \\
\text { the institution }\end{array}$} & No night shift ${ }^{1}$ & $16.60 \pm 7.79$ & $12.40 \pm 6.06$ & $4.60 \pm 3.04$ \\
\hline & Close to home ${ }^{2}$ & $18.92 \pm 4.13$ & $17.61 \pm 7.24$ & $6.69 \pm 5.42$ \\
\hline & $\begin{array}{l}\text { Non-heavy working } \\
\text { conditions }^{3}\end{array}$ & $22.00 \pm 5.12$ & $19.12 \pm 10.98$ & $8.50 \pm 7.54$ \\
\hline & Economic reasons ${ }^{4}$ & $18.38 \pm 5.28$ & $16.76 \pm 6.12$ & $7.53 \pm 3.64$ \\
\hline & Designation 5 & $21.37 \pm 4.85$ & $18.67 \pm 5.67$ & $7.07 \pm 3.93$ \\
\hline & Test values & $K W=2.25 p=0.06$ & $\mathrm{KW}=1.25 \mathrm{p}=0.29$ & $\mathrm{KW}=0.64 \mathrm{p}=0.63$ \\
\hline & & $1-2 p=0.90,1-3 p=0.33$ & $1-2 p=0.55,1-3 p=0.37$ & $1-2 p=0.90,1-3 p=0.54$ \\
\hline & & $1-4 p=0.96,1-5 p=0.25$ & $1-4 p=0.71,1-5 p=0.24$ & $1-4 p=0.72,1-5 p=0.76$ \\
\hline & & $2-3 p=0.65,2-4 p=0.99$ & $2-3 p=0.98,2-4 p=0.99$ & $2-3 p=0.89,2-4 p=0.98$ \\
\hline & & $2-5 p=0.50,3-4 p=0.49$ & $2-5 p=0.98,3-4 p=0.92$ & $2-5 p=0.99,3-4 p=0.98$ \\
\hline & & $3-5 p=0.99,4-5 p=0.30$ & $3-5 p=1.00,4-5 p=0.87$ & $3-5 p=0.91,4-5 p=0.99$ \\
\hline \multirow[t]{6}{*}{ Economic status } & Income $<$ expense $^{1}$ & $20.77 \pm 2.94$ & $20.55 \pm 4.47$ & $8.11 \pm 3.62$ \\
\hline & Income $=$ expense $^{2}$ & $20.47 \pm 5.13$ & $17.34 \pm 6.07$ & $6.67 \pm 4.39$ \\
\hline & Income $>$ expense $^{3}$ & $20.71 \pm 5.56$ & $18.09 \pm 7.46$ & $8.00 \pm 5.13$ \\
\hline & Test values & $\mathrm{F}=0.80 \mathrm{p}=0.52$ & $F=0.80 p=0.52$ & $F=0.5 p=0.71$ \\
\hline & & $1-2 p=0.65,1-3 p=0.45$ & $1-2 p=0.75,1-3 p=0.65$ & $1-2 p=0.97,1-3 p=0.88$ \\
\hline & & $2-3 p=0.40$ & $2-3 p=0.88$ & $2-3 p=0.76$ \\
\hline \multirow[t]{8}{*}{ Transportation type } & On foot ${ }^{1}$ & $18 \pm 9.22$ & $20.25 \pm 4.97$ & $7.08 \pm 5.33$ \\
\hline & With shuttle 2 & $14.88 \pm 4.73$ & $20.77 \pm 5.76$ & $6.61 \pm 4.27$ \\
\hline & Public transportation ${ }^{3}$ & $19.45 \pm 7.69$ & $20.54 \pm 5.31$ & $7.15 \pm 4.39$ \\
\hline & Own car ${ }^{4}$ & $17.87 \pm 4.45$ & $19.12 \pm 2.85$ & $7.5 \pm 4.47$ \\
\hline & Test values & $K W=0.40 p=0.80$ & $K W=1.34 p=0.26$ & $K W=0.67 p=0.61$ \\
\hline & & $1-2 p=0.99,1-3 p=0.99$ & $1-2 p=0.57,1-3 p=0.96$ & $1-2 p=0.99,1-3 p=0.9$ \\
\hline & & $1-4 p=0.96,2-3 p=0.99$ & $1-4 p=0.09,2-3 p=0.10$ & $1-4 p=0.99,2-3 p=0.97$ \\
\hline & & $2-4 p=0.87,3-4 p=0.88$ & $2-4 p=0.70,3-4 p=0.97$ & $2-4 p=0.96,3-4 p=0.99$ \\
\hline \multirow[t]{6}{*}{ Annual leave time (week) } & 2 weeks $^{1}$ & $20.00 \pm 5.45$ & $17.58 \pm 6.76$ & $7.35 \pm 4.30$ \\
\hline & 3 weeks $^{2}$ & $20.88 \pm 4.95$ & $19.11 \pm 6.62$ & $7.51 \pm 4.66$ \\
\hline & 4 weeks $^{3}$ & $21.10 \pm 4.77$ & $17.83 \pm 6.23$ & $6.20 \pm 4.32$ \\
\hline & Test values & $F=0.96 p=0.41$ & $F=0.51 p=0.67$ & $F=0.58 p=0.62$ \\
\hline & & $1-2 p=0.91,1-3 p=0.83$ & $1-2 p=0.81,1-3 p=0.99$ & $1-2 p=0.74,1-3 p=0.99$ \\
\hline & & $2-3 p=0.99$ & $2-3 p=0.88$ & $2-3 p=0.68$ \\
\hline
\end{tabular}




\begin{tabular}{lll}
$\begin{array}{l}\text { Table 4. Satisfaction Questionnaire Scores of the nurses } \\
(\mathrm{n}=95)\end{array}$ & Mean \pm SD \\
\hline Scale & Subscale & $3.27 \pm 0.66$ \\
Satisfaction & Intrinsic satisfaction & $2.85 \pm 0.75$ \\
Questionnaire & Extrinsic satisfaction & $3.10 \pm 0.65$ \\
\hline & General satisfaction &
\end{tabular}

Kaplanoğlu (14) found in his study that the job satisfactions of the nurse managers were moderate. The effectiveness of the clinics in which nurses work on job satisfaction levels can be explained by nurse and patient profile in surgical clinics. In surgical clinics, patients with acute conditions are hospitalized and the patient is discharged in a short time. Yllmaz (15), showed that the nurses working in emergency

Table 5. Satisfaction Questionnaire scores of the nurses in terms of socio-demographic and professional variables $(n=95)$

\begin{tabular}{|c|c|c|c|c|}
\hline Variable & Variable categories & $\begin{array}{l}\text { Intrinsic satisfaction } \\
\text { (1-5 points) } \\
\text { Mean } \pm \text { SD }\end{array}$ & $\begin{array}{l}\text { Extrinsic satisfaction } \\
\text { (1-5 points) } \\
\text { Mean } \pm \text { SD }\end{array}$ & $\begin{array}{l}\text { General satisfaction } \\
(1-5 \text { points }) \\
\text { Mean } \pm \text { SD }\end{array}$ \\
\hline \multirow[t]{3}{*}{ Gender } & Female & $3 \pm 0.59$ & $2.9 \pm 0.76$ & $3.16 \pm 0.63$ \\
\hline & Male & $2.73 \pm 0.68$ & $2.65 \pm 0.71$ & $2.88 \pm 0.68$ \\
\hline & Test values & $t=1.69 p=0.09$ & $t=1.31 p=0.19$ & $t=1.74 p=0.08$ \\
\hline \multirow[t]{6}{*}{ Age } & $20-24$ years $^{1}$ & $3.03 \pm 0.58$ & $3.11 \pm 0.65$ & $3.26 \pm 0.6$ \\
\hline & 30-34 years 3 & $2.85 \pm 0.62$ & $2.73 \pm 0.81$ & $3 \pm 0.67$ \\
\hline & $35-39$ years $^{4}$ & $2.92 \pm 0.48$ & $2.71 \pm 0.53$ & $3.04 \pm 0.47$ \\
\hline & 40 years and over 5 & $3.26 \pm 0.35$ & $3.2 \pm 0.72$ & $3,44 \pm 0.50$ \\
\hline & Test values & $F=1.1 p=0.33$ & $F=1.7 p=0.15$ & $F=1.4 p=0.24$ \\
\hline & & $3-5 p=0.41,4-5 p=0.73$ & $3-5 p=0.40,4-5 p=0.52$ & $3-5 p=0.34,4-5 p=0.58$ \\
\hline \multirow[t]{3}{*}{ Marital Status } & Married & $2.88 \pm 0.65$ & $2.92 \pm 0.71$ & $3.09 \pm 0.67$ \\
\hline & Single & $2.99 \pm 0.60$ & $2.79 \pm 0.78$ & $3.11 \pm 0.64$ \\
\hline & Test values & $t=0.83 p=0.4$ & $t=0.84 p=0.39$ & $t=0.13 p=0.89$ \\
\hline \multirow{5}{*}{$\begin{array}{l}\text { Number } \\
\text { of children }\end{array}$} & None $^{0}$ & $2.88 \pm 0.68$ & $2.84 \pm 0.77$ & $3.06 \pm 0.69$ \\
\hline & 1 child ${ }^{1}$ & $3.02 \pm 0.57$ & $2.7 \pm 0.87$ & $3.09 \pm 0.67$ \\
\hline & 2 children and more 2 & $3.03 \pm 0.49$ & $3.02 \pm 0.57$ & $3.22 \pm 0.51$ \\
\hline & Test values & $F=0.56 p=0.57$ & $F=0.92 p=0.40$ & $F=0.42 p=0.65$ \\
\hline & & $0-1 p=0.66,0-2 p=0.68$ & $0-1 p=0.73,0-2 p=0.64$ & $0-1 p=0.98,0-2 p=0.63$ \\
\hline \multirow{3}{*}{$\begin{array}{l}\text { Educational } \\
\text { status }\end{array}$} & & $1-2 p=0.50,1-3 p=0.70$ & $1-2 p=0.68,1-3 p=0.66$ & $1-2 p=0.78,1-3 p=0.70$ \\
\hline & & $1-4 p=0.72,2-3 p=1.00$ & $1-4 p=0.59,2-3 p=1.72$ & $1-4 p=0.99,2-3 p=1.00$ \\
\hline & & $2-4 p=0.90,3-4 p=0.87$ & $2-4 p=0.89,3-4 p=0.99$ & $2-4 p=0.95,3-4 p=0.94$ \\
\hline \multirow{4}{*}{$\begin{array}{l}\text { Duration of } \\
\text { Working in the } \\
\text { institution }\end{array}$} & $1-3$ years $^{1}$ & $3.06 \pm 0.71$ & $3.11 \pm 0.78$ & $3.28 \pm 0.7$ \\
\hline & 4-8 years ${ }^{2}$ & $2.61 \pm 0.71$ & $2.44 \pm 0.71$ & $2.73 \pm 0.71$ \\
\hline & $9-11$ years $^{3}$ & $3.03 \pm 0.71$ & $2.94 \pm 0.84$ & $3.19 \pm 0.66$ \\
\hline & $12-15$ years $^{4}$ & $2.89 \pm 0.54$ & $2.75 \pm 0.54$ & $3.04 \pm 0.45$ \\
\hline
\end{tabular}




\section{Table 5. Continued}

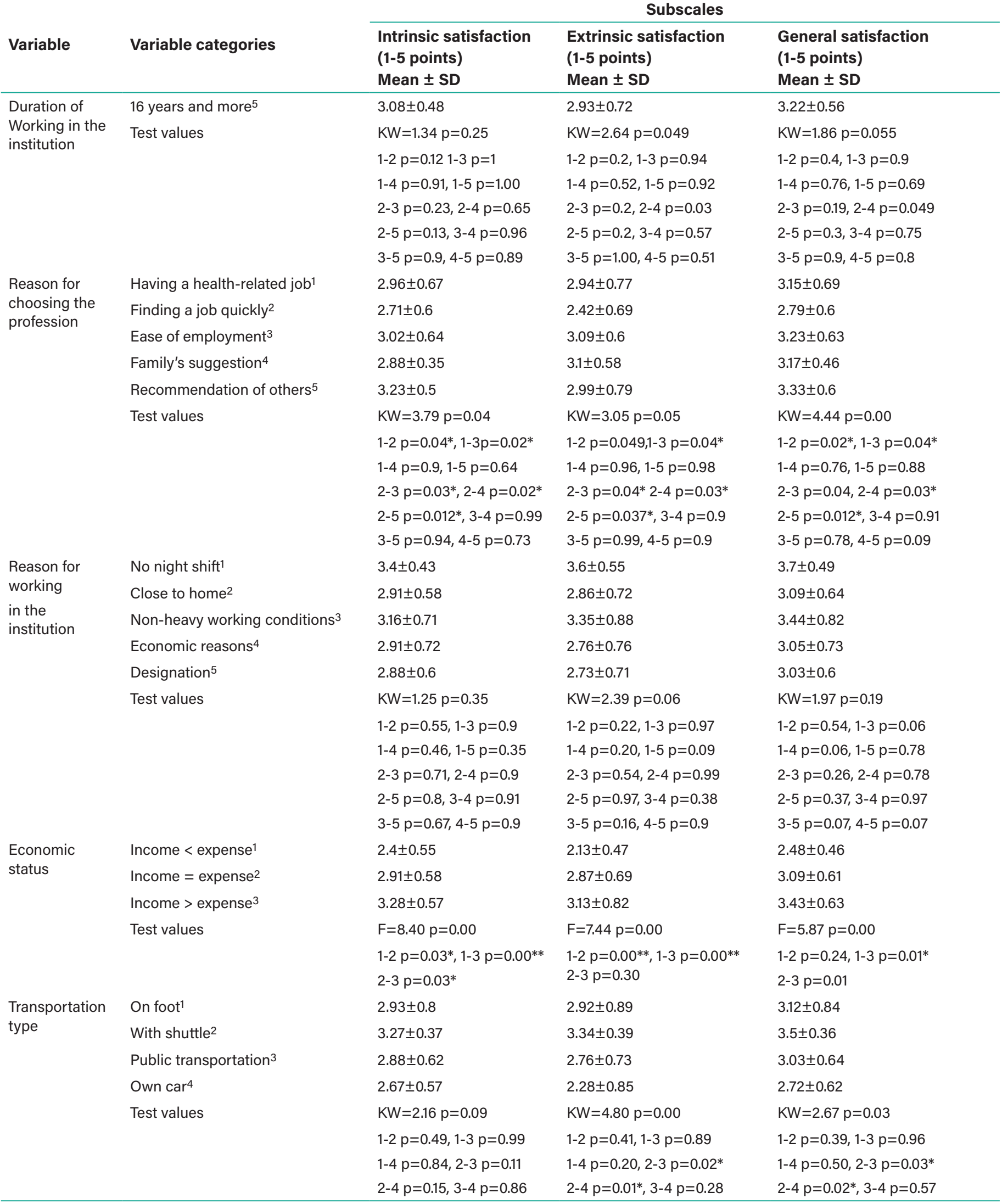


Table 5. Continued

\begin{tabular}{|c|c|c|c|c|}
\hline \multirow[b]{2}{*}{ Variable } & \multirow[b]{2}{*}{ Variable categories } & \multicolumn{3}{|c|}{ Subscales } \\
\hline & & $\begin{array}{l}\text { Intrinsic satisfaction } \\
\text { (1-5 points) } \\
\text { Mean } \pm \text { SD }\end{array}$ & $\begin{array}{l}\text { Extrinsic satisfaction } \\
\text { (1-5 points) } \\
\text { Mean } \pm \text { SD }\end{array}$ & $\begin{array}{l}\text { General satisfaction } \\
\text { (1-5 points) } \\
\text { Mean } \pm \text { SD }\end{array}$ \\
\hline \multirow{6}{*}{$\begin{array}{l}\text { Annual leave } \\
\text { time (week) }\end{array}$} & 2 weeks $^{1}$ & $3.09 \pm 0.63$ & $3.02 \pm 0.8$ & $3.26 \pm 0.67$ \\
\hline & 3 weeks $^{2}$ & $2.68 \pm 0.64$ & $2.6 \pm 0.7$ & $2.87 \pm 0.67$ \\
\hline & 4 weeks $^{3}$ & $2.99 \pm 0.52$ & $2.85 \pm 0.63$ & $3.13 \pm 0.54$ \\
\hline & Test values & $F=3.40 p=0.06$ & $F=2.59 p=0.08$ & $F=2.58 p=0.05$ \\
\hline & & $1-2 p=0.047^{*}, 1-3 p=0.80$ & $1-2 p=0.036,1-3 p=0.61$ & $1-2 p=0.04 *, 1-3 p=0.05$ \\
\hline & & $2-3 p=0.16$ & $2-3 p=0.40$ & $2-3 p=0.31$ \\
\hline
\end{tabular}

F: One-way analysis of variance, KW: Kruskal-Wallis test, t: Student t-test, ${ }^{*} \mathrm{p}<0.05 ;{ }^{*} \mathrm{p}<0.01$

surgical intensive care unit had lowest satisfaction compared the other nurses.

In this study, there was no difference between female and male nurses in terms of burnout and job satisfaction. Ünal et al., (16) found that the life satisfaction scores of women were higher than men, but Özçınar (17) study found that job satisfaction did not differ according to gender. Rafii et al. (18) showed that there is a significant relationship between burnout and gender in the studied nurses.

The emotional exhaustion and depersonalization levels of the nurses were higher in the age group of 25-29 years than the age groups of 20-24 years and 40 years and over. Sayll et al., (19) found no significant correlation between the age and burnout level. Again, the difference between the job satisfactions and the age groups of the nurses was not significant. Yürümezoğlu (20), Ay and Karakaya (21), and Aksakal et al., (22) stated that the job satisfaction of nurses was not affected by age.

There was no significant difference between the married and single nurses in terms of burnout and job satisfaction. Similarly, in the studies by Çam (23), Kaplanoğlu (14), and Çam et al., (24), any significant correlation was not found between the marital status and burnout.

In this study, depersonalization level of the nurses with no children was found to be higher than the nurses with two and more children. However, there was no significant difference between the burnout scale and the other subscales of the satisfaction questionnaire. A study reveals that there is a significant relationship between burnout and the number of children.

In studies, single and non-children, it was found to be more risky in terms of depersonalization and burnout. This situation is explained that the problem solving skills may be improved as the result of the married people dealing with crises and having more experience in interpersonal relations $(25,26)$.

Similarly, the difference between the economic status and burnout and job satisfaction was not significant in the studies by Tunç (27) and Çam (23). In contrast to the study, Taycan et al., (10) showed that the job satisfaction scores of the nurses who had incomes higher than their expenses were higher than the others. In their studies, Ay and Karakaya (21), Çalışkan (28), and Demir (29) also showed the low income as a reason for dissatisfaction.

In the present study, it was found that personal accomplishment levels of the nurses with a working duration of 9-11 years in the institution were lower than other nurses. This shows that burnout is high in this group. In the study by Erçevik (30), opposite results were found. No significant difference was found between the variable of working duration and job satisfaction. In the study by Güleç (31) no significant difference was found between the duration of working in the hospital and the job satisfaction total score. In the study of Kebapci and Akyolcu (32), it was found that nurses who had the highest number of working hours in the profession and nurses in most studies had the highest personal accomplishment. In our study nurses with a working duration of 16 years and above were found to have high personal accomplishment scores compared to nurses with a working duration of 9-11 years.

Job satisfaction total score, intrinsic satisfaction subscale score and extrinsic satisfaction subscale scores of the nurses who chose the profession due to the finding a job quickly were lower than the other nurses. According to today's conditions, finding a job quickly is an important factor in choosing a profession rather than finding the profession appropriate for him/herself. In the study by Keskin and Ylldırım (33) job satisfaction mean scores of the nurses 
who expressed their satisfaction with their profession were found to be higher.

The difference between the reason of choosing the institution and the burnout and job satisfaction of the sample group was not significant. In the studies, it is stated that willingness to choose the profession is an important factor affecting the level of burnout. it was found that the general satisfaction and intrinsic satisfaction subscale scores of the healthcare personnel who chose the profession voluntarily were higher $(34,35)$.

No difference was observed between the transportation type and burnout levels of the nurses. It was determined that the general job satisfaction score and extrinsic satisfaction subscale scores of the nurses who used shuttle were higher than the nurses using public transportation and their own vehicles. This included the shuttle namely the transportation facilities. It is seen that using public transportation and personal cars negatively affects nurses in both material and immaterial aspects with traffic problem.

No correlation was determined between the annual leave and burnout levels in the study. Job satisfaction, general satisfaction scores, and subscale scores of the nurses with annual leave of 2 weeks were found to be higher than those with annual leave of 3 weeks. It is possible to think that the job satisfaction increases with the confidence caused by working together with the adaptation to the new job since the nurses who have freshly started the job use minimum leave. At the same time the high level of income in this group may have affected this situation.

A negative significant correlation was determined between the job satisfaction and emotional exhaustion and depersonalization of the nurses. Regardless of the institution the nurses work, doing their jobs willingly and sticking with the job will increase the motivation at work [Arcak and Kasımoğlu (36)] and affect the job satisfaction positively by decreasing the emotional exhaustion and depersonalization. Negative properties of the working environment such as low number of employed nurses, heavy workload and insufficient rewarding can be considered as responsible (37). This is a factor for the nurses to feel tired and emotionally worn (19).

\section{Conclusion}

In this study, variables of age, number of children and duration of working in the institution was found to affect the burnout in nurses working in surgical clinics. In addition, economic situation, reason for choosing the profession, transportation type and annual leave time variables were seen to affect job satisfaction in nurses. It can be thought that the cases like improving shifts, working hours, wages, holiday and social activities, number of nurses, service facilities of those working with shifts, training and selfimprovement opportunities, and development of working environment/conditions had similar effects in all of the nurses working in the surgical clinics. Studies can be conducted to improve and develop them.

\section{Ethics}

Ethics Committee Approval: The study was approved by the Haliç University Ethics Committee was received (approval number: 44-2012).

Informed Consent: Informed Consent from patients.

Peer-review: Externally peer-reviewed.

\section{Authorship Contributions}

Concept: N.K., H.Y., E.Y., K.Ö., Design: N.K., H.Y., E.Y., K.Ö. Data Collection or Processing: N.K., H.Y., E.Y., K.Ö., Analysis or Interpretation: N.K., H.Y., E.Y., Literature Search: N.K., H.Y., E.Y., K.Ö., Writing: N.K., H.Y., E.Y., K.Ö.

Conflict of Interest: No conflict of interest was declared by the authors.

Financial Disclosure: The authors declared that this study received no financial support.

\section{References}

1. Torun A. Tükenmişlik Aile Yapısı Ve Sosyal Destek İlişkileri Üzerinde Bir İnceleme, Doktora Tezi, İstanbul:1995.

2. Bilge $\mathrm{F}$, Akman $\mathrm{Y}$, Kelecioğlu H. Öğretim Elemanlarının İş Doyumlarının İncelenmesi. Hacet U Egit Fak 2007;32:32-41.

3. Haran S, Özgüven HD, Ölmez Ş. Ankara üniversitesi tıp fakültesi hastaneleri ve Ankara Numune Hastanesi'nde çalışan doktor ve hemşirelerde tükenmişlik düzeyleri. Kriz Derg 1998;6:75-84.

4. Acar E. Uzmanlık alanında çalışmanın iş doyumuna etkisi. Paradoks Ekonomi, Sosyoloji ve Politika Dergisi 2007;3:1-18.

5. Piko BF. Burnout, role conflict, job satisfaction and psychosocial health among Hungarian health care staff: a questionnaire survey. Int J Nurs Stud 2006;43:311-318.

6. Le Moual N, Varraso R, Zock JP, Henneberger P, Speizer FE, Kauffmann F, et al. Are operating room nurses at higher risk of severe persistent asthma? the nurses' health study. J Occup Environ Med 2013;55:973-977.

7. Paris M Jr, Hoge MA. Burnout in the mental health workforce: a review. J Behav Health Serv Res 2010;37:519-528.

8. Ergin C. Doktor ve hemşirelerde tükenmişlik ve Maslach Tükenmişlik Ölçeğinin uyarlanması. VII. Ulusal Psikoloji Kongresi Bilimsel Çalışmaları, Ankara:1993. 
9. Baycan F. Farklı gruplarda çalışan gruplarda iş doyumunun bazı yönlerinin analizi. Bilim Uzmanlığı Tezi. İstanbul Boğaziçi Üniversitesi, İstanbu:1985.

10. Taycan O, Kutlu L, Çimen S, Aydın N. Bir Üniversite Hastanesinde Çalışan Hemşirelerde Depresyon ve Tükenmişlik Düzeyinin Sosyodemografik Özelliklerle İlişkisi. Anadolu Psikiyatr De 2006;7:100-108.

11. Metin Ö, Özer FG. Hemşirelerin tükenmişlik düzeyinin belirlenmesi, Atatürk Üniversitesi Hemşirelik Yüksekokulu Dergisi 2007;10:58-66.

12. Barutçu E, Serinkan C. günümüzün önemli sorunlarından biri olarak tükenmişlik sendromu ve denizlide yapılan bir araştırma, Ege Akademik Bakış 2008;8:541-561.

13. Cilingir D, Gürsoy A, Colak A. Burnout and job satisfaction in surgical nurses and other ward nurses in a tertiary hospital: a comparative study in Turkey. Health Med 2012;6:120.

14. Kaplanoğlu A. Yönetici hemşirelerin atılganlık düzeyleri ile iş doyumu arasindaki ilişki. Marmara Üniversitesi Sağlık Bilimleri Enstitüsü, Yüksek Lisans Tezi. İstanbul:2007

15. Yılmaz M. Sağlık bakım kalitesinin bir ölçütü: hasta memnuniyeti. Cumhuriyet Üniversitesi Hemşirelik Yüksekokulu Dergisi 2001;5:69-74.

16. Ünal S, Karlıdağ R, Yoloğlu S. Hekimlerde işdoyumu ve tükenmişlik düzeyleri. Klinik Psikiyatri Dergisi 2001;4:113-118.

17. Özçınar M. Asistan doktorlarda burnout sendromu, Dr. Lütfü Kırdar Kartal Eğitim ve Araştırma Hastanesi Aile Hekimliği, Aile Hekimliği Uzmanlık Tezi, İstanbul:2005.

18. Rafii F, Shamsikhsni S, Zarei M, Haghani M. Burnout and its Relationship with the Nurses' Characteristics. Iranian Journal of Nursing Research 2012;25:23-33.

19. Sayıl I, Haran S, Ölmez Ş. Ankara Üniversitesi Hastanelerinde Çalışan Doktor ve Hemşirelerin Tükenmişlik Düzeyleri. Kriz Dergisi 1997;5:71-77.

20. Yürümezoğlu HA. Yataklı tedavi kurumlarında çalışan hemşirelerin iş doyumları ve hastaların hemşirelik hizmetinden memnuniyeti. Dokuz Eylül Üniversitesi Sağlık Bilimleri Enstitüsü, Yüksek Lisans Tezi, İzmir:2007.

21. Ay A, Karakaya A. Çalışanların motivasyonunu etkileyen faktörler. Sağlık Çalışanlarına Yönelik Bir Araştırma. C.Ü. Sosyal Bilimler Dergisi 2007;31:55-67.

22. Aksakal NF, Özkan S, Baycan Z, Aycan S. Gölbaşı bölgesinde birinci basamak sağlık kuruluşlarında çalışan sağlık personelinin mesleki memnuniyet durumları. Sağlık ve Toplum Dergisi 1999;9:9-14.

23. Çam O. Hemşirelerin tükenmişlik düzeyleri ve tükenmişliği etkileyen bazı etmenlerin incelenmesi. Cumhuriyet Üniversitesi Hemşirelik Yüksekokulu Dergisi 1992;456-461.
24. Çam O, Akgün E, Gümüş BA, Bilge A, Keskin UG. Bir ruh sağlı̆̆ hastanesinde çalıșan hekim ve hemşirelerin klinik ortamlarını değerlendirmeleri ile iş doyumları arasındaki ilişkinin incelenmesi. Anadolu Psikiyatri Dergisi 2005;6:213-220.

25. Çimen M, Ergin C. Türk Silahlı Kuvvetleri sağlık personelinin tükenmişlik düzeylerinin incelenmesi. Gülhane Tıp Dergisi 2001;43:169-176.

26. Günüşen NP, Ustün B. An RCT of coping and support groups to reduce burnout among nurses. Int Nurs Rev 2010;57:485-492.

27. Tunç T. Doktor ve hemşirelerde tükenmişlik ile rol çatışması ve rol belirsizliği arasındaki ilişki, Tez danışmanı; Doç. Dr. Rana Özen Kutanis, Özkan Matbaacılık, Ankara:2007.

28. Çalışkan Z. İș tatmini: Malatya'da sağllk kuruluşları üzerine bir uygulama. Doğu Anadolu Bölgesi Araştırmaları Dergisi 2005;4:918.

29. Demir N. Örgüt kültürü ve iş tatmini. Türmen Kitabevi, İstanbul 2007;197-279.

30. Erçevik R. Hemşirelerde işe bağlı gerginlik, tükenmişlik düzeyleri ve etkileyen faktörler. Haliç Üniversitesi Sağlık Bilimleri Enstitüsü, Danışman: Yard. Doç. Dr. Nefise Bahçecik. Yayınlanmamış Yüksek Lisans Tezi, İstanbul:2010.

31. Güleç D. Rotasyon İle Çalışan Hemşirelerde İş Doyumunun Belirlenmesi. Marmara Üniversitesi Sağllk Bilimleri Enstitüsü. Yüksek Lisans Tezi, İstanbul: 2009

32. Kebapcı A, Akyolcu N. Acil birimlerde çalışan hemşirelerde çalışma ortamının tükenmişlik düzeylerine etkisi. Türkiye Acil Tıp Dergisi 2011;11:59-67.

33. Keskin G, Yıldırım GÖ. Hemşirelerin Kișisel Değerlerinin ve İş Doyumlarının İncelenmesi. Ege Üniversitesi Hemşirelik Yüksekokulu Dergisi 2006;22:119-133.

34. Sinat Ö. Psikiyatri Kliniklerinde Çalışan Hemşirelerde Tükenmișlik Düzeyinin Araştırılması, İstanbul Üniversitesi Sağlı Bilimleri Enstitüsü, Psikiyatri Hemşireliği ABD, Yüksek Lisans Tezi, İstanbul:2007.

35. Altuğ IIY, Susur A, Keskin S, Balcı Y, Seber G. Osmangazi Üniversitesi Tıp Fakültesi'nde çalışan hekimlerde tükenmişlik düzeyleri, Osmangazi Tıp Dergisi 2006;28:91-101.

36. Arcak R, Kasımoğlu E. Diyarbakır merkezdeki hastane ve sağlık ocaklarında çalışan hemşirelerin sağlık hizmetlerindeki rolü ve iş memnuniyetleri. Dicle Tip Dergisi 2006;33:23-30.

37. Ebrinç S, Açıkel C, Başoğlu C, Çetin M, Çeliköz B. Yanık merkezi hemşirelerinde anksiyete, depresyon, iş doyumu, tükenme ve stresle başa çıkma: karşılaştırmalı bir çalışma. Anadolu Psikiyatri Dergisi 2002;3:162-168. 